\title{
Fatty acids and mineral composition of melon (Cucumis melo L. Inodorus) seeds from West Algeria
}

\author{
Naima Bouazzaoui, Wassila Drici, Wafaa Bouazzaoui, Wafaa Lemerini, Zoheir Arrar, Djamel \\ Bendiabdellah and Joseph Kajima Mulengi*
}

Laboratoire of Organic Chemistry,Natural Products and Analysiss (COSNA). University of Tlemcen. P.O. Box 119 Tlemcen 13000, Algeria. Tel. \& Fax: 0021343215886

\begin{abstract}
Seeds of melon (Cucumis melo L. Inodorus) were analyzed for their mineral and lipid compositions. The seeds showed a 30.7\%lipids content and ashes accounted for $4.08 \%$. Freshly extracted oil showed acid and peroxide values respectively $4.01 \mathrm{mg} \mathrm{KOH} / \mathrm{g}$ and $2.25 \mathrm{Meq}\left(\mathrm{O}_{2}\right) / \mathrm{Kg}$. Iodine and saponification values were $104.52 \mathrm{~g}\left(\mathrm{I}_{2}\right) / 100 \mathrm{~g}$ and $193.60 \mathrm{mg}(\mathrm{KOH}) / \mathrm{g}$ respectively. Main fatty acids identified so far were linoleic, oleic, palmitic and stearic acids with respective contents $60.1 \%, 25.3 \%, 10.1 \%$ and $4.5 \%$. Mineral analysis revealed significant levels of potassium, magnesium, calcium and sodium, namely 509.80, 101.71, 55.39 and 41.17 $\mathrm{mg} / 100 \mathrm{~g}$ respectively
\end{abstract}

Keywords: Cucumis melo, Fatty acids, Mineral content, Diabetes, Cardiovascular diseases.

\section{Introduction}

Recently, increased attention has been focused on the use of undervalued agricultural products such as by-products and wastes to produce food and feed. Such utilization would help improve exploitation of available resources and minimize waste disposal concerns. A number of surveys were performed on the seeds oil from different wild plants which indicate that those could become promising oil sources for many goals such as nutritional and medicinal purposes ${ }^{1-5}$.

Melon (Cucumis melo L. Inodorus) is one of the most widely grown vegetable crops throughout the warm regions in the world. It accounts among major vegetable products of widespread consumption in Algeria generating a huge amount of seeds. However, unless this waste deserves investigation, it is generally thrown away which might be considered an economical and nutritional loss.

Vegetable oils are known to be mainly made of triglycerides, namely triacylglycerols of fatty acids. A number of investigations have shown their beneficial effects on health as a whole through exploration of physiological and molecular mechanisms of their action ${ }^{6}$.

Their beneficial effects to health care were evidenced in such fields as the prevention and coronary heart disease ${ }^{7,8}$, hypertension ${ }^{9,10}$, type 2 diabetes ${ }^{11,12}$, Parkinson's ${ }^{13}$ and Alzheimer'diseases.
The global consumption of oils is dominated by palm, soybean, rapeseed and sunflower oils with respectively $39.0,35.8,18.0$ and 10.0 million tons production per year ${ }^{15}$. To the best of our knowledge, industrial production of oil from melon seeds or its use as a food supplement is unknown in Algeria; this is due to lack of information on the chemical composition and nutritional properties of these seeds. Therefore the present work was undertaken with an aim to analyzing the fatty acids and mineral composition of the seeds melon in order to set forth the possible beneficial effects on economy and health.

\section{Results and Discussion}

\section{Chemical analysis}

Chemical composition of melon (Cucumis melo L. Inodorus) seeds was determined. We found a high percentage of oil $30.7 \%$, . Working on seeds of Cucumis melo Inodorus grown Malaysia, Yanty et al. found lower contents of oil $(25.0 \%)^{16}$.. This difference arises from geographical conditions. Similar values were reported by De Melo ${ }^{17}$ (30.83\%) and De Mello ${ }^{18}(32.3 \%)$ in seeds of Cucumis melo hybrid and Cucumis melo var. saccharinus respectively. The highest content (40\%) was reported by Sorho ${ }^{19}$ in seeds Cucumis amaris.

Analysis of dry seeds of Cucumis melo L. Inodorus showed $4.0 \%$ ash and $6.0 \%$ moisture. That were similar compared with values $6.0 \%$ and $3.9 \%$ reported by De Mello ${ }^{18}$.
*Corresponding author: Joseph Kajima Mulengi
E-mail address: cosnalab@yahoo.fr
DOI: http://dx.doi.org/10.13171/mjc.5.1/0160130/kajima 


\section{Mineral composition}

Table 1 shows the mineral content of ash. The highest content was observed for potassium $(\mathrm{K})$ with $509.80 \mathrm{mg} / 100 \mathrm{~g}$ followed by magnesium $(\mathrm{Mg})$ 101.71, whereas moderate contents were obtained for calcium $(\mathrm{Ca}), 55.39$ and sodium $(\mathrm{Na}), 41.17 \mathrm{mg} / 100 \mathrm{~g}$ respective.

Table 1. Mineral composition of melon (Cucumis melo L. Inodorus) seeds as compared to the literature.

\begin{tabular}{|c|c|c|c|}
\hline \multirow{2}{*}{ Mineral } & \multicolumn{3}{|c|}{ Content mg/100g } \\
\hline & Present study & $\begin{array}{l}\text { Citrullus vulgaris } \\
\text { Melon seeds }\end{array}$ & $\begin{array}{c}\text { (Citrullis } \\
\text { colocynthis)elon seed }{ }^{21}\end{array}$ \\
\hline Cadmium & traces & - & - \\
\hline Iron & 4.90 & 5.8 & 4.2 \\
\hline Copper & 0.83 & 2.8 & 1.88 \\
\hline Plumb & 0.11 & - & - \\
\hline Manganese & 1.66 & 3.3 & - \\
\hline Nickel & 0.11 & - & - \\
\hline Magnesium & 101.71 & 657.7 & 210 \\
\hline Calcium & 55.44 & 130.7 & 103.5 \\
\hline Potassium & 509.80 & 1140.0 & 770 \\
\hline Sodium & 41.22 & 118.0 & - \\
\hline Zinc & 4.77 & 9.6 & 3.9 \\
\hline
\end{tabular}

These results are in close agreement with those reported by Olaofe ${ }^{20}$ and Milovanovic ${ }^{21}$ as regards two different varieties of melon seeds. Manganese $(\mathrm{Mn})$, copper $(\mathrm{Cu})$, iron $(\mathrm{Fe})$ and zinc $(\mathrm{Zn})$ accounted for minor contents i.e. 1.59, 0.83, 4.90 and 4.65 $\mathrm{mg} / 100 \mathrm{~g}$ respectively. Those percentages are comparable to those reported by Olaofe $^{20}$ and Milovanovic21. The presence of such chemical elements as $\mathrm{K}, \mathrm{Ca}, \mathrm{Zn}, \mathrm{Na}$, traces of nickel, etc. in foodstuffs was already reported for their important contribution to the maintenance of normal glucose levels and tolerance ${ }^{22}$.

These elements might contribute to the fight against the resistance to the release of insulin from the body ${ }^{22}$. Only traces of cadmium $(\mathrm{Cd})$, cobalt $(\mathrm{Co})$ and nickel (Ni) were found.

The presence of those minor components in the sample might be due to specific soils composition of the region or attributed to exhausts from zinc works nearby. This needed an extensive survey of soils and vegetables of the region to check and compare their mineral content. But this survey is beyond the scope of our investigation.

\section{Oil physicochemical features}

The following physical and physicochemical characteristics were measured and/or observed (Table 2): specific density, 0.897; refractive index, 1.470. Similar values were reported by De Mello ${ }^{18}$ and Sorho ${ }^{19}$. The iodine value of our sample was 104.52 lower than 109.6, 112 and 117.2 reported by De Mello ${ }^{18}$, De Melo ${ }^{17}$ and Sorho ${ }^{19}$ respectively. This would mean that our sample contained less polyunsaturated fatty acids than literature samples. In the meantime our oil showed an acidic value (4.01), higher than the one reported by De Mello ${ }^{18}$ but lower than the one reported by Sorho ${ }^{19}$. As far as peroxide and saponification indexes were concerned, our sample displayed a low peroxide value (2.25) as compared to results reported by De Mello ${ }^{18}$, whereas saponification value was 193.6 comparable to values found by De Melo ${ }^{17}$ and Sorho ${ }^{19}$ groups. Needless to point out that a low peroxide value indicates that this oil withstands autoxidation as observed when analysis showed with fresh oil. Nevertheless it would advisable to store fatty acids methyl esters (FAMEs) and the corresponding acids in the cold in order to preserve them from degradation. 
Table 2. Physicochemical data of oil from melon (Cucumis melo L. Inodorus) seeds as compared to literature

\begin{tabular}{|c|c|c|c|c|}
\hline Parameter & Present study & Melon seed oil ${ }^{20}$ & Melon seed oil ${ }^{21}$ & Melon seed oil ${ }^{15}$ \\
\hline $\begin{array}{c}\text { Specific gravity } \\
\left(25^{\circ} \mathrm{C}, \mathrm{g} / \mathrm{mL}\right)\end{array}$ & $0.897 \pm 0.0019$ & $0.949 \pm 0.0021$ & $0.900 \pm 0.0018$ & $0.90 \pm 0.002$ \\
\hline $\begin{array}{l}\text { Refractive index } \\
\qquad\left(25^{\circ} \mathrm{C}\right)\end{array}$ & $1.4707 \pm 0.003$ & $1.478 \pm 0.0015$ & $1.482 \pm 0.0120$ & $1.47 \pm 0.002$ \\
\hline $\begin{array}{l}\text { Acid value (mg } \\
\mathrm{KOH} / \mathrm{g} \text { oil) }\end{array}$ & $4.01 \pm 0.02$ & $1.8 \pm 0.10$ & $2.06 \pm 0.15$ & $6.06 \pm 0.02$ \\
\hline $\begin{array}{l}\text { Peroxide value } \\
\left(\mathrm{Meq}\left(\mathrm{O}_{2}\right) / \mathrm{Kg}\right)\end{array}$ & $2.25 \pm 0.05$ & $4.00 \pm 0.03$ & $4.96 \pm 0.10$ & $34.40 \pm 0.04$ \\
\hline $\begin{array}{l}\text { Iodine value (g } \\
\mathrm{I}_{2} / 100 \mathrm{~g} \text { oil) }\end{array}$ & $104.52 \pm 0.48$ & $109.606 \pm 0.55$ & $112.00 \pm 1.82$ & $117.02 \pm 0.71$ \\
\hline $\begin{array}{c}\text { Saponification } \\
\text { value }(\mathrm{mg} \mathrm{KOH} / \mathrm{g} \\
\text { oil) }\end{array}$ & $193.60 \pm 0.85$ & $191.404 \pm 0.90$ & $210.62 \pm 0.53$ & $192.30 \pm 0.95$ \\
\hline
\end{tabular}

\section{Fatty acids composition analysis}

GC-MS analysis of FAMEs showed four major peaks (Figure 1). The identification of FAMEs was performed by first running the standards followed by the analysis of our sample under identical analytical conditions.
Too small peaks were not considered since they could be part of background or artifacts. GC FID and GC-MS analysis were performed at least three times for reproducibility.

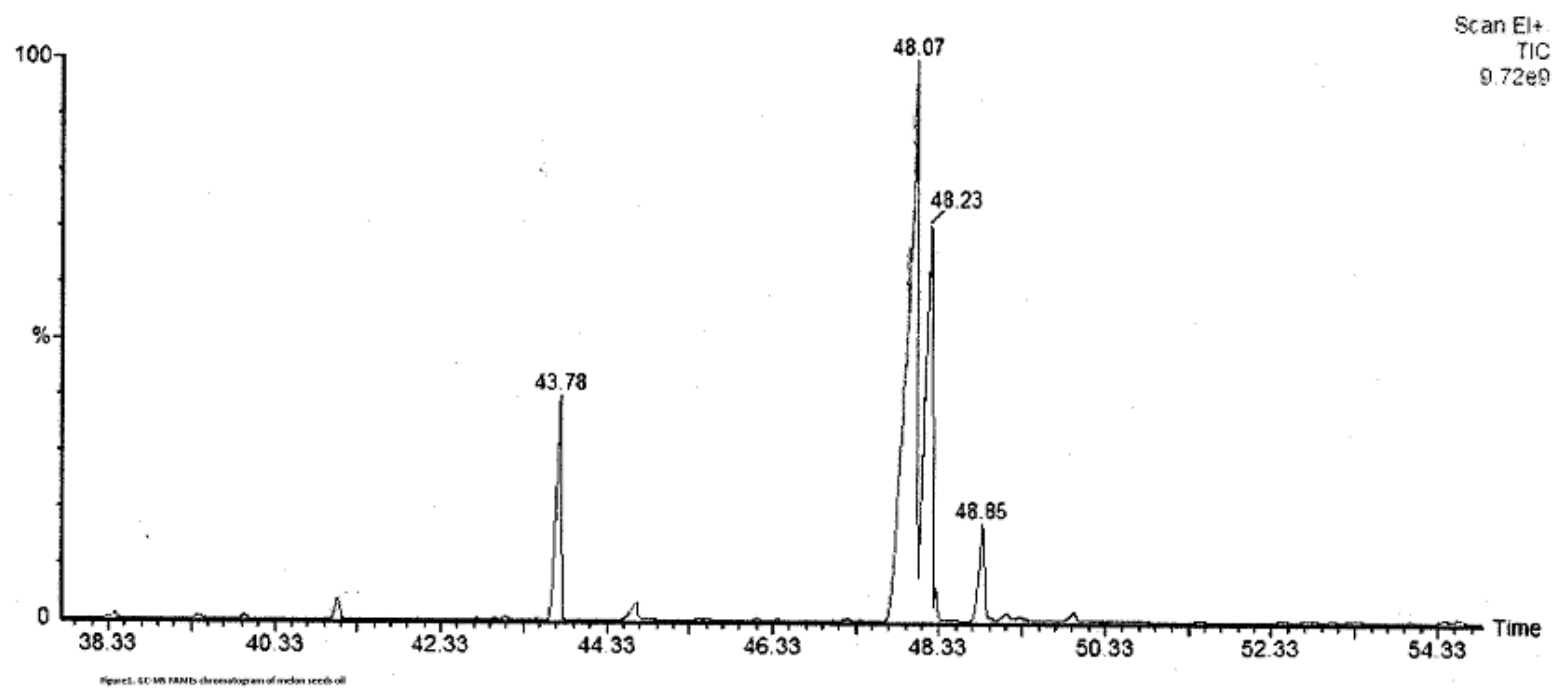

Figure 1. GC-MS chromatogram of melon (Cucumis melo L. Inodorus) seeds oil

GC-MS analysis of FAMEs showed our sample contained two saturated fatty acid esters namely methyl palmitate (Figure 2) and methyl stearate acids, along with two unsaturated fatty acid esters, i.e. methyl linoleate (Figure 3) and methyl oleate. The following fatty acids were found and they are mentioned with their percentages and retention times $(\mathrm{rt})$ : Linoleic $(\mathrm{C} 18: 2)$ was the main fatty acid that accounted for $60.1 \%$ (rt 48.07) of the mixture, followed by oleic acid (C18:1), 25.3\% (rt 48.23), whereas minor components were palmitic acid (C16:0) 10.1\% (rt 43.80) and stearic acid (C18:0) $4.5 \%$ (rt 48.90) respectively. The base peak in all mass spectra of saturated FAMEs was observed at $\mathrm{m} / \mathrm{z} \quad 74 \quad$ (Figure 2), corresponding to $\mathrm{CH}_{3} \mathrm{OC}\left(=\mathrm{OH}^{+}\right) \mathrm{CH}_{2}$ fragment which was a result of the well-known McLafferty rearrangement process followed by an alpha fragmentation ${ }^{23}$. 


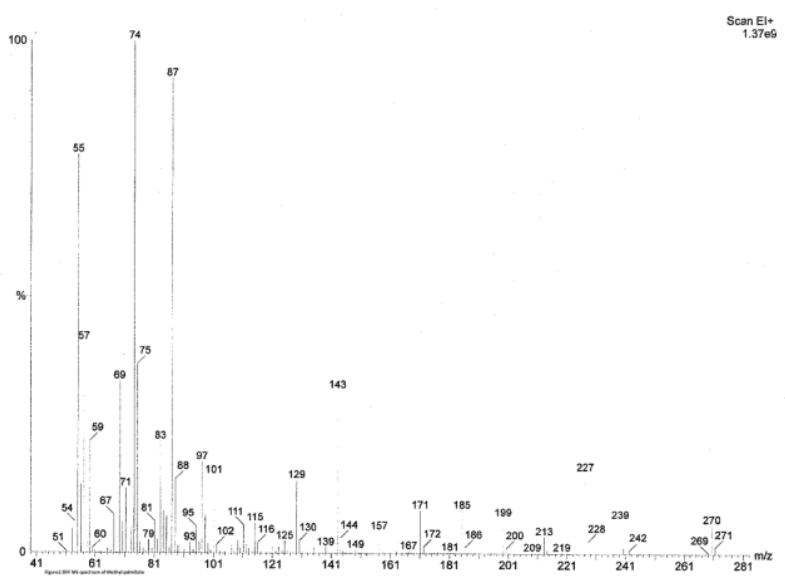

Figure 2. Mass spectrum of methyl palmitate.

The base peak of monounsaturated FAME (oleic acid methyl ester) was observed at $\mathrm{m} / \mathrm{z} 55$, as a consequence of the McLafferty rearrangement process and was observed at $\mathrm{m} / \mathrm{z} 222$ and the peak at $\mathrm{m} / \mathrm{z} 264[\mathrm{M}-32]^{+}$corresponded to a loss of methoxy group plus hydrogen atom (Supplementary information).

The fragmentation of polyunsaturated FAMEs, exemplified by Figure 3 showed a characteristic base peak at $\mathrm{m} / \mathrm{z} 67$ corresponding to the loss of hydrocarbon ion of general formula $\left[\mathrm{C}_{n} \mathrm{H}_{2 \mathrm{n}-3}\right]^{+}$, where $\mathrm{n}=5$. A prominent ion peak at $\mathrm{m} / \mathrm{z} 220$ [M$74]^{+}$was due to loss of McLafferty ion, while an ion at $\mathrm{m} / \mathrm{z} 263$ [M-31] was a result of the loss of methoxy group. Other hydrocarbon ions $\left[\mathrm{C}_{\mathrm{n}} \mathrm{H}_{2 \mathrm{n}-3}\right]^{+}$ prevail in the lower mass range $(\mathrm{m} / \mathrm{z}=81,95,109$, 123 , etc).

Besides, we compared contents of fatty acids from other known edible oils such as pumpkin, palm, sunflower and soybean along with another variety of melon seeds in Table 4.

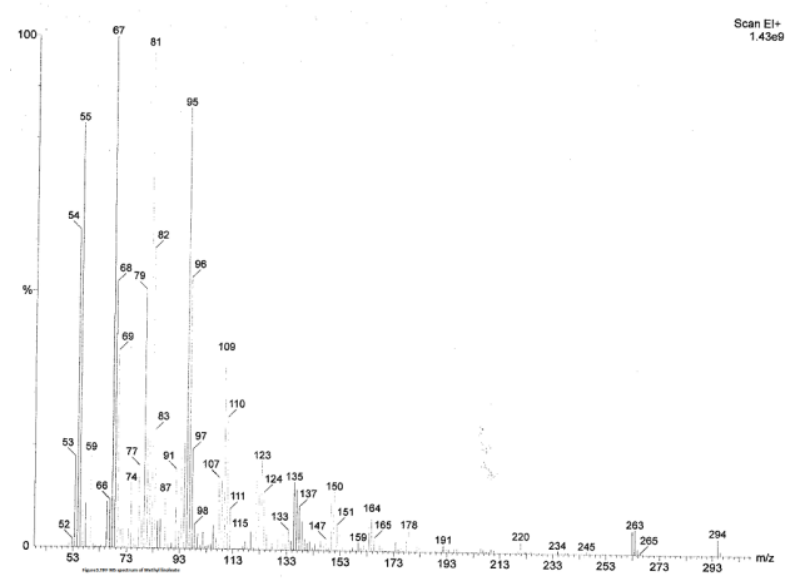

Figure 3. Mass spectrum of methyl linoleate.

De Mello ${ }^{18}$ and De Melo ${ }^{17}$ also found linoleic acid as the main fatty acid followed by oleic acid, palmitic and stearic acid for the oil extracted from two other varieties of Cucumis melo. Polyunsaturated fatty acids (PUFAs) content of edible oils is an important and basic parameter that mainly accounts for evaluating their nutritional value ${ }^{24}$. Sunflower oil showed the most interesting content in PUFAs with linoleic acid as the major component $(66.2 \%)^{25}$. In our sample this fatty acid was also the most representative $60.1 \%$ whereas palm, soybean and pumpkin oils were respectively made of just $(10.1 \%, 53.2 \% \text { and } 42.6 \%)^{25,26}$. By contrast, monounsaturated fatty acids (MUFA) contents from other sources are mainly found in palm oil $(39.2 \%$ )$^{25}$, followed by pumpkin with $36.8 \%{ }^{26}$ whereas our sample is richer in MUFAs $25.3 \%$ than sunflower oil $(21.1 \%)^{25}$. As far as saturated fatty acids contents were concerned, melon (Cucumis melo L.Inodorus) seeds oil is made of $14.6 \%$, lower than palm oil $(49.9 \%)^{25}$, pumpkin oil $(20.3 \%)^{26}$, soybean oil $(15.1 \%){ }^{25}$ whereas its content is higher than sunflower oil $(11.3 \%)^{25}$.

Table 3. Fatty acids composition from different sources (\%)

\begin{tabular}{|c|c|c|c|c|c|c|c|}
\hline Fatty acids & $\begin{array}{l}\text { Present } \\
\text { study }\end{array}$ & $\begin{array}{c}\text { Melon } \\
\text { oil }^{18}\end{array}$ & $\begin{array}{c}\text { Melon } \\
\text { oil }^{17}\end{array}$ & $\begin{array}{c}\text { Pumpkin } \\
\text { oil }^{26}\end{array}$ & $\underset{\text { oil }^{25}}{\text { Palm }}$ & $\begin{array}{c}\text { Sunflower } \\
\text { oil }^{25}\end{array}$ & $\begin{array}{c}\text { Soybean } \\
\text { oil }^{25}\end{array}$ \\
\hline Myristic(C14:0) & - & 0.073 & 0.04 & - & 1.1 & - & 0.1 \\
\hline Palmitic(C 16:0) & 10.1 & 8.51 & 9.52 & 13.1 & 44.0 & - & 11.0 \\
\hline Stearic (C18:0) & 4.5 & 6.089 & 4.89 & 6.10 & 4.5 & 4.5 & 4.0 \\
\hline Oleic (C18:1) & 25.3 & 31.5 & 19.42 & 35.9 & 39.2 & 21.1 & 23.4 \\
\hline Linoleic (C18:2) & 60.1 & 51.6 & 64.13 & 42.6 & 10.1 & 66.2 & 53.2 \\
\hline Linolenic(C18:3) & - & 0.190 & 0.20 & 0.25 & 0.04 & - & 7.8 \\
\hline SFA & 14.6 & 15.36 & 15.2 & 20.3 & 49.9 & 11.3 & 15.1 \\
\hline MUFA & 25.3 & 32.10 & 20.1 & 36.8 & 39.2 & 21.1 & 23.4 \\
\hline PUFA & 60.1 & 51.79 & 64.3 & 43.0 & 10.5 & 66.2 & 61.0 \\
\hline
\end{tabular}

Saturated fatty acids (SFA), monounsaturated fatty acids (MUFAs), polyunsaturated fatty acids (PUFAs)

FTIR analysis of FAMEs

FTIR analysis was used to check the efficiency of the protocol for esterification. As a rule, GC and/or GC-MS analysis of fatty acids is usually performed after their conversion into methyl esters. Therefore, previous to GC or GC/MS analysis, one should give evidence for the full conversion of fatty acids into their methyl esters and not perform 
analysis with mixture of carboxylic acids and esters. That is why FTIR analysis was used to check the full disappearance of carboxylic absorption bands in the region $3200-2500 \mathrm{~cm}^{-1}$ and the presence of esters.

All samples showed spectral features according to literature ${ }^{27,28}$, namely characteristic absorption bands for carbonyl $\mathrm{C}=\mathrm{O}$ at $1744.21 \mathrm{~cm}^{-1}$ and $\mathrm{C}-\mathrm{O}$ stretching vibration at $1170.19 \mathrm{~cm}^{-1}, 1195.56 \mathrm{~cm}^{-1}$ and $1242.03 \mathrm{~cm}^{-1}$. The methyl group from lipid was generally observed at $2926.64 \mathrm{~cm}^{-1}$ and $2854.83 \mathrm{~cm}^{-}$ 1 . Absorption bands appearing at $1463.04 \mathrm{~cm}^{-1}$ and $1437.01 \mathrm{~cm}^{-1}$ were attributed to the $\mathrm{C}-\mathrm{H}$ non symmetric and symmetric deformation vibrations, respectively. The absorption at $723 \mathrm{~cm}^{-1}$ was due to $\mathrm{C}-\mathrm{H}$ bond from alkane long chains ${ }^{29}$.

\section{Conclusion}

In this paper, we investigate the composition of oil from seeds of melon (Cucumis melo L. Inodorus) from west Algeria in an attempt to boost its economical and nutritional use. The physicochemical properties, mineral content and fatty acids composition were determined. Our results showed that melon (Cucumis melo L. Inodorus) seeds are an important source of minerals, namely $\mathrm{K}, \mathrm{Ca}$ and $\mathrm{Mg}$. Magnesium is showing increasing interest for the adequate heart function; its presence would be taken advantage of for people with limited resources.

Moreover this oil showed interesting amounts of unsaturated fatty acids as compared to other known edible oils. As nutritionists generally recommend a Mediterranean diet especially for cardiovascular concerns, melon seeds oil could be taken advantage of for its content of both linoleic and oleic acids as food supplements to improve health conditions.

\section{Acknowledgements}

The authors are indebted to General Directorate for Scientific Research and Technological Development (Higher Ministry of Higher Education and Scientific Research-Algeria) for financial support.

\section{Experimental Section}

\section{Seeds}

Melon (Cucumis melo L. Inodorus) seeds were obtained in June 2013 from Boukhnais (GhazaouetTlemcen), a northwestern region of Algeria, close to the Mediterranean Sea. The seeds were got rid of any vegetable residue, washed with water, and finally dried in the air. After completion of drying there were ground in a blender and screened through a $1.12 \mathrm{~mm}$ mesh diameter. Then the resulting powder was stored in a refrigerator.

\section{Statistical analysis}

The satistical analysis was obtained using the function from Microsoft Office Excel. For each analysis, values presented are the means of triplicate determination. The difference between two analysis varied between 0 and 0.5 for mineral analysis. All values recorded in Table 2 are presented as means of triplicate determination with standard deviations. The level of significance was set at $\mathrm{p}<0.05$.

Chemical analysis

Moisture, lipid and ash contents were determined following the standard AOAC (1990) methods ${ }^{30}$.

\section{Mineral composition}

The mineral composition of melon seeds was analyzed as described by Oloyede $(2005)^{31}$. Briefly, a sample was incinerated at $550^{\circ} \mathrm{C}$ in a furnace; ash ( $1 \mathrm{~g})$ was boiled in $20 \%$ hydrochloric acid solution $(10 \mathrm{ml})$ in a beaker and cooled. The resulting solution was filtered into a $100 \mathrm{ml}$ standard volumetric flask. Then deionized water was added to make a total $100 \mathrm{ml}$ solution. The resulting solution was analyzed for its mineral composition and content using Atomic Absorption Spectroscopy (Aurora AI 1200).

\section{Lipid extraction}

Powder of ground seeds (15 g) was extracted at $70^{\circ} \mathrm{C}$ with n-hexane $(100 \mathrm{ml})$ for $6 \mathrm{~h}$ in a soxhlet extractor. Then n-hexane was removed at $40^{\circ} \mathrm{C}$ under reduced pressure using a rotary evaporator. The residual oil was stored at $-20^{\circ} \mathrm{C}$ until use.

Physicochemical properties of oill

Density and refractive index were determined at room temperature $\left(28^{\circ} \mathrm{C}\right)$ using a densitometer and a refractometer, respectively. Acid, peroxide, iodine and saponification values were determined according to literature AOAC 1997 Methods $^{32}$.

Esterification of fatty acids.

The mixture of fatty acids was first saponified followed by esterification with methanol (MeOH) using Boron trifluoride-methanol complex $\left(\mathrm{BF}_{3^{-}}\right.$ $\mathrm{MeOH}$ ) as a catalyst the final method was a result of slight modification of existing methods ${ }^{17-24}$. A typical procedure was performed as follows: oil (3g) was hydrolyzed on reflux for $1 \mathrm{~h}$ with $1.0 \mathrm{M}$ potassium hydroxide solution $(50 \mathrm{ml})$ in $95 \%$ ethanol $(\mathrm{EtOH})$. Water $(100 \mathrm{ml})$ was added to the cold solution and the mixture was extracted thrice with diethyl ether $\left(\mathrm{Et}_{2} \mathrm{O}\right)(50 \mathrm{ml})$.

The aqueous layer was acidified with $6.0 \mathrm{M}$ hydrochloric acid and then was extracted three times with hexane $(50 \mathrm{ml})$. The free fatty acids were recovered after washing the combined organic extracts with water, drying over anhydrous sodium sulfate and removal of the solvent. Fatty acids were then converted into the corresponding methyl esters (FAMEs) using $\mathrm{BF}_{3}-\mathrm{MeOH}$ complex (14\% w/v). 
The mixture was maintained at $90^{\circ} \mathrm{C}$ for $1-5 \mathrm{~min}$ and the reaction was quenched by dipping the reaction vial in an ice bath. FAMEs were extracted thrice with hexane $(50 \mathrm{ml})$ and the combined organic extracts were dried over anhydrous sodium sulfate $\left(\mathrm{Na}_{2} \mathrm{SO}_{4}\right)$ and the solvent was removed in vacuo. The resulting esters mixture needed no further purification and was stored at $-20^{\circ} \mathrm{C}$ until analysis.

\section{GC-FID and GC-MS.}

Qualitative and quantitative analysis of FAMEs were performed on GC-MS Perkin Elmer (Clarus). A Perkin Elmer Elite-5 capillary column (5\% diphenyl dimethylpolysiloxane, $30 \mathrm{~m} \times 0.25 \mathrm{~mm} \times 0.25 \mu \mathrm{m})$ was used. Analytical Helium (1 $\mathrm{ml} / \mathrm{min})$ was used as the carrier gas and the injector operated at $200^{\circ} \mathrm{C}$. After a series of attempts for optimizing the analysis, we determined the best experimental conditions of FAMEs according to the column we used. The analysis was performed using a program-temperature gradient, namely $40^{\circ} \mathrm{C}$ for $4.1 \mathrm{~min}$, then from $40^{\circ} \mathrm{C}$ to $210^{\circ} \mathrm{C}$ with a gradient $4^{\circ} \mathrm{C} / \mathrm{min}$ and then $15 \mathrm{~min}$ at $210^{\circ} \mathrm{C} .1 \mu \mathrm{l}$ of extract was injected in the split mode with a $1: 10$ ratio.

Electronic impact (EI $70 \mathrm{eV}$ ) was used to run mass fragmentation. Components were identified and quantified by their retention times and mass spectra as compared to data gathered from authentic commercial standards analysis in the same experimental conditions (Supelco 37-FAMEs Mix47885-U as well as palmitic, oleic, stearic and linoleic acids FAMEs). GC analysis was performed on a Shimadzu GC-17A instrument using a specific column for FAMEs (Capillary Column Teknokroma TR-CN100, 30mx0.25mmx0.20 $\mu \mathrm{m})$.

\section{FTIR analysis}

Infrared spectra were acquired using a Mattson Genesis II FTIR spectrometer using neat samples on $\mathrm{NaCl}$ cells.. Absorption bands were identified according to their wave numbers $\left(\mathrm{cm}^{-1}\right)$.

\section{References}

1- C. Nergiz, I. Donmez, Chemical composition and nutritive value of Pinuspinea $L$ seeds, Food Chem, 2004, 86, 365-368. http://www.sciencedirect.com/science/article/pii/ $\underline{\text { S0308814603004746 }}$

2- M. Ennouri et al., Effect of diet supplementation with Cactus pear seeds and oil on serum and liver lipid parameters in rats, Food Chem, 2007, 101 , 248-253. http://www.opuntiaseedoil.com/images/rech/effe ct.p

3- A. Jelassi, I. Cheraief, M.A. Hamza, H. Ben Jannet, Chemical composition and characteristic profiles of seed oils from three Tunisian Acacia species, J Food Comp Anal, 2014, 33, 49-54. http://www.sciencedirect.com/science/article/pii/ S088915751300135X

4- S. Karakaya, A. Kavas, S. Nehir El, N. Gunduç, L. Akdogn, Nutritive value of a melon seed beverage, Food Chem, 1995, 52, 139-141. http://www.sciencedirect.com/science/article/pii/ 0308814694P4193J

5- R. Horax, N. Hettiarachchy, A. Kannan, P. Chen, Protein extraction optimisation, characterisation, and functionalities of proteinisolate from bitter melon (Momordica charantia) seed, Food Chem, 2011, 124, 545550.

http://www.sciencedirect.com/science/article/pii/ S030881461000779X

6- S. Walrand, F. Fisch, J. M. Bourre, Do saturated fatty acids have the same metabolic effect? Nutr Clin. Metabol, 2010, 24, 63-75. http://www.emconsulte.com/en/article/252314

7- M. L. Burr et al., Effect of changes in fat, fish and fibre intakes on death and myocardial reinfarction: diet and reinfarction trial (DART), The Lancet, 1989, 334, 757-761.

http://www.thelancet.com/journals/lancet/article/ PIIS0140-6736(89)90828-3/abstract

8- M. De Lorgeril et al., Mediterranean alpha linolenic acid-rich diet in secondary prevention of coronary heart disease. The Lancet, 1994, 343, 1454-1459.

http://www.ncbi.nlm.nih.gov/pubmed/7911176

9- H. L. Harbild, L. B. S. Harsløf, J. H. Christensen, K. N. Kannass, L. Lauritzen, Fish oil-supplementation from 9 to 12 months of age affects infant attention in a free-play test and is related to change in blood pressure, Prostaglandins Leukot Essent Fatty Acids (PLEFA), 2013, 89, 327-333.

http://www.plefa.com/article/S09523278(13)00164-6/abstract

10- M. S. Chi, R. L. Ray, D. C. Williams, M. V. Tuig, K. Galbreath, Effect of dietary fat on blood pressure and plasma lipids in spontaneously hypertensive rats, Nutr Res, 1999, 19, 917-925. http://cat.inist.fr/?aModele=afficheN\&cpsidt=19 $\underline{01637}$

11- K. A. Meyer, L. H. Kushi, J. D. R. Jacobs, A. R. Folsom, Dietary fat and incidence of type 2 diabetes in older Iowa women, Diabetes Care, 2001, 24, 1528-1535.

http://care.diabetesjournals.org/content/24/9/152 8.full.pdf

12- J. Salmeron, F. B. Hu, J. E. Manson, M. J. Stampfer, G. A. Colditz, E. B. Rimm, W. C. Willett, Dietary fat intake and risk of type 2 diabetes in women, Am J Clin Nutr, 2001, 73, 1019-1026.

http://ajcn.nutrition.org/content/73/6/1019.full.p df+html 
13- J. Dong, J. D. Beard, D. M. Umbach, Y. Park, X. Huang, A. Blair, F. Kamel, H. Chen, H. Mov Dietary fat intake and risk for Parkinson's disease, Mov Disorders, 2014, 29, 1623-1630. http://onlinelibrary.wiley.com/doi/10.1002/mds. 26032/abstract

14- P. A. Dacks, D. W. Shineman, H. M. Fillit, Current evidence for the clinical use of longchain polyunsaturated $n-3$ fatty acids to prevent age-related cognitive decline and Alzheimer's disease, J Nutr Health Aging, 2013, 17, 240251.

http://link.springer.com/article/10.1007/s12603012-0431-3

15- USDA (2007): Foreign Agricultural Service (FAS ) of the Department of Agriculture US.

16- N. A. M. Yanty, O. M. Lai, A. Osman, H. M. Ghazali, Physicochemical properties of Cucumis melo Var. Inodorus (Honeydew Melon) seed and seed oil. J. Food Lipids 2008, 15, 42-55.

17- M. L. S. De Melo, N. Narain, P. S. Bora, Characterisation of somme nutritional constituents of melon (Cucumis melohybrid AF522) seeds, Food Chem, 2000, 68, 411-414. http://www.sciencedirect.com/science/article/pii/ S0308814699002095

18- M. L. S. De Mello, P. S. Bora, N. Narain, Fatty and Amino Acids Composition of Melon (Cucumis melo Var. saccharinus) Seeds, J Food Comp Anal, 2001, 14, 69-74.

http://www.sciencedirect.com/science/article/pii/ S0889157500909529

19- S. Sorho, S. Yaya, A. A. Augustin, L. Laurent, Multivariate calibration by variable selection for blends of raw soybean oil/ biodiesel from different sources using Fourier Transform Infrared Spectroscopy (FT-IR) spectra data, J Appl Sci, 2006, 15, 3167-3169.

http://scialert.net/qredirect.php?doi=jas.2006.31 67.3169\&linkid=pdf

20- O. Olaofe, F. O. Adeyemi, G. O. Adediran, Amino Acid and Mineral Compositions and Functional Properties of Some Oil seeds, J Agri Food Chem, 1994, 42, 878-881.

http://pubs.acs.org/doi/abs/10.1021/jf00040a007

21- M. Milovanović, K. Pićurić-Jovanović, Characteristic and Composition of Melon Seed Oil, J Agric Sci, 2005, 50, 41-47. http://www.doiserbia.nb.rs/img/doi/14508109/2005/1450-81090501041M.pdf

22- a-K. A. Choudhary, N. G. Bandyopadhyay, Preliminary studies on the inorganic constituents of some indigenous hyperglycaemic herbs on oral glucose tolerance test, J Ethnopharmacol, 1999, 64, 179-184.

http://europepmc.org/abstract/med/10197754 b- K. O. Soetan, C. O. Olaiya, O. E. Oyemole,
The importance of mineral elements for humans, domestic animals and plants : a review. African J; Food Science 2010, 4(5), 200-222

23- F. W. McLafferty, Mass spectrometric analysis, molecular rearrangement, Anal Chem, 1959, 31, 82-87.

http://pubs.acs.org/doi/abs/10.1021/ac60145a015

24- A. F. Luzzi, W. P. T. James, European diet and public health: The continuing challenge, Public Health Nutr, 2001, 4, 275-292.

http://journals.cambridge.org/download.php?file =\%2FPHN\%2FPHN4_2a\%2FS1368980001001

549a.pdf\&code $=64283 \mathrm{f} 0 \mathrm{ae} 4 \mathrm{e} 44 \mathrm{e} 869 \mathrm{ea} 5 \mathrm{e} 022 \mathrm{a} 6 \mathrm{~d}$ $\mathrm{f} 2 \mathrm{e} 32$

25- D. O. Edem, Palm oil: biochemical, physiological, nutritional, hematological and toxicological aspects: a review, Plant Foods Hum Nutr, 2002, 57, 319-341.

http://link.springer.com/article/10.1023\%2FA\%3 A1021828132707

26- A. Nawirska-Olszanska, A. Kita, A. Biesiada, A. Sokol-Letowska, A. Z. Kucharska, Characteristics of antioxidant activity and composition of pumpkin seed oils in 12 cultivars, Food Chem, 2013, 139, 155-161.

http://www.sciencedirect.com/science/article/pii/ $\underline{\text { S0308814613001684 }}$

27- I. P. Soares, T. F. Rezende, R. C. Silva, E. V. R. Castro, I. C. P. Fortes, Multivariate Calibration by Variable Selection for Blends of Raw Soybean Oil/Biodiesel from Different Sources Using Fourier Transform Infrared Spectroscopy (FTIR) Spectra Data, Energy Fuels, 2008, 22, 2079-2083.

http://pubs.acs.org/doi/abs/10.1021/ef700531n?j ournalCode $=$ enfuem

28- M. D. Guillen, N. Cabo, Infrared spectroscopy in the study of edible oils and fats, J Sci Food Agric, 1997, 75, 1-11.

http://onlinelibrary.wiley.com/doi/10.1002/(SICI 1097-0010(199709)75:1\%3C1::AIDJSFA842\%3E3.0.CO;2-R/abstract

29- M. N. Nabi, S. M. Hoque, M. S. Akhter, Karanja (Pongamiapinnata)biodiesel production in Bangladesh, characterization of karanja biodiesel and its effect on diesel emissions, Fuel Process Technol, 2009, 90, 1080-1086. http://www.sciencedirect.com/science/article/pii/ S037838200900109X

30- AOAC (1990). Official Methods of Analysis, $15^{\text {th }}$ Ed. Association of Official Analytical Chemists, Washington, DC.

31- O. I. Oloyede, Chemical profile of unripe pulp of Cartica papaya, Pakistan Journal of Nutrition (PJN), 2005, 4, 379-381. http://www.pjbs.org/pjnonline/fin328.pdf

32- AOAC (1997). Official Methods and recommended practices of the American Oil Chemists' Society ( $5^{\text {th }}$ ed.).Champaign. USA: AOAC Press. 